\title{
AN ENTREPRENEURIAL EDUCATION MODEL FOR THE NAMIBIAN HIGHER EDUCATION SYSTEM
}

\author{
P Ras, Tshwane University of Technology \& M Pretorius, University of Pretoria, South Africa
}

\begin{abstract}
Purpose: The aim of this paper is to develop an entrepreneurial education model for implementation in the Namibian Higher Education system. Namibia, just like South Africa, has an objective to develop small, medium and micro enterprises to enhance economic growth and reduce unemployment. Development of such a model is supported by the government of Namibia. This paper investigates appropriate entrepreneurial education models used in South Africa for this purpose.
\end{abstract}

Design/Methodology/Approach: This research is an exploratory research design based upon secondary data mainly provided by the Namibian Economic Policy Research Unit (NEPRU) that enabled the researcher to understand and identify the problems that Namibia encounter in their small business environment. Theories, as developed by the University of Pretoria based on entrepreneurial education, were explored and formed the base of the theory exploration.

Findings: The researcher investigated an existing entrepreneurial education model being used for the South African context, as well as a comparison of two models, and an integrated model based on the cited models. These models are used to show the importance of such models and the need to develop one for Namibia.

Implications: This paper presents a model that can solve the basic need expressed by the Namibian Higher Education System to find an appropriate model to implement.

Originality/ Value: This paper provides a foundation from which an entrepreneurial education model can be implemented and improved/customised for the Namibian context

Key words and phrases: Entrepreneurial models, Entrepreneurial Education.

\section{INTRODUCTION}

"Education is a human right with immense power to transform. On its foundation rest the corner stones of freedom, democracy and sustainable human development". Coffie Annan

Employment creation in Namibia has featured extensively on the government's agenda. The National Development Plan (NDP1) lists employment creation as one of four major goals of the plan along with reviving and sustaining economic growth, reducing inequalities in income distribution and eradicating poverty. Over the past five years unemployment in Namibia has increased to 34.8\% (Ministry of Labour). With an economic growth rate of three percent per annum, it does not seem that this problem will be solved in the near future. Based on this information, it would seem that little or no job opportunities will be available in the near future for the unemployed, school leavers, and tertiary educated leavers. A logical approach to solve this would be to follow the direction envisaged in the NDP, to encourage job creation.

The Polytechnic of Namibia is currently in the process of revising its current curricula on request of the Ministry of Trade and Industry to provide appropriate training programmes to meet this demand of fostering the Small, Medium, and Micro Enterprises (SMME). The current enterprise density of Namibia is below two percent, this is relatively low compared to other countries in the SADC, such as South Africa (2\%), Lesotho (3.3\%), and Swaziland at (4.1\%) (Ntsika, 1997:18). The enterprise density indicator reflects scope for new venture creation in Namibia. This gives rise to an opportunity to develop and introduce courses in entrepreneurship at undergraduate level.

The Global Competitiveness report (2003/2004) indicates that Namibia has moved up to the third place among the SADC countries in terms of its economic environment. However the quality of its business environment has shown the opposite, it has moved from second to the fourth place. The main reasons 
cited in this regard were the lack of scientists and engineers and poor or inadequate management schools.

Van Vuuren and Nieman (1998) state that, according to Welsch, entrepreneurship education has, in the last decade, grown in stature and numbers as a popular and innovative part of business curriculum. This opportunity to train entrepreneurs can lead African higher education to explore curricula from other higher education institutions to meet its needs in terms of finding the appropriate curricula. Gibbons (1998) made a number of observations in his book on "Higher Education Relevance in the $21^{\text {st }}$ Century". He indicated the following trends:

"The main change that will take place is that knowledge production and dissemination will no longer be self-contained activities, carried out in relative isolation. The challenge will be to get knowledge that may have been produced anywhere in the world to the place where it can be used effectively."

The focus of this exploratory paper is to firstly explore the content of a model developed by the University of Pretoria forming the base of their entrepreneurship program. Secondly a model developed in a doctoral thesis, then an article where a comparison is done on the mentioned two models and lastly an article where an integrated model is proposed are explored

\section{PROBLEM STATEMENT}

The primary problem addressed in this paper is:

- How to improve the entrepreneurial performance of the Namibian business environment by means of a training intervention.

Various secondary problems can be derived:

- Is conventional training and development the tool to use to improve the Namibian business environment?

- Can a formal university education syllabus or curriculum be structured to provide a solution for job creation?

\section{PROPOSITION}

P1: The components of the entrepreneurial education model used by the University of Pretoria integrated with a doctoral thesis can successfully be implemented in the Namibian context.

\section{METHODOLOGY}

This research is an exploratory research design based upon secondary data mainly provided by Namibia (NEPRU) that enabled the researcher to understand and identify the problems that Namibia encounter in their small business environment. Theories as developed by the University of Pretoria based on entrepreneurial education were explored and formed the base of the theory exploration.

The research is based on secondary data. As a starting point, the higher education system of Namibia was approached and no appropriate entrepreneurial education models could be found at either the University of Namibia or the Polytechnic of Namibia to be evaluated in terms of its content and applicability to enhance the SMME sector. Secondary data was obtained from the Department of Trade and Industry, and the Polytechnic in the form of policy and work documents. Scientific data was obtained from NEPRU to give an understanding of the Namibian phenomenon. The curricula of tertiary institutions of higher education in South Africa were explored, that can address the phenomenon. The data collection focused on finding curricula that can provide an appropriate entrepreneurial education programme that 
leads up to a formal qualification. A partial limitation to the study was the availability of reliable data for SADC regions.

\section{IMPORTANCE OF THE PAPER}

The importance of the paper is embedded in the entrepreneurial education models used in the education process in a developing country, namely South Africa. The first by the University of Pretoria and the second model that of a doctorate thesis at TUT.

The purpose of this paper is to make a purposeful contribution to enhancing the business environment of Namibia that is also a developing country, by means of an entrepreneurial education model used to govern the education process and content thereof.

\section{FINDINGS}

Bygrave (1994:33) stated the following about performance:

"We cannot ensure that entrepreneurship training would create a Bill Gates or any other successful entrepreneur that you know of, as a physics professor would not be able to graduate you an Albert Einstein , but give us a student/course attendant with a orientation towards business and we can improve the performance of such an individual"

From the above statement, a question can be posed: can the performance of an individual be improved with an entrepreneurial education intervention? According to a primary study done by Henry, Hill and Leitch (2005:101), individuals will be able to benefit from: learning an innovative approach to problem solving; adapting more readily to change; becoming more self-reliant and developing their creativity through the study of entrepreneurship.

Accepting this reported outcome, it is necessary to choose an appropriate entrepreneurial intervention for the specific need expressed for a specific target market. In the case of Namibia, the target market is BTech graduates from all disciplines with the objective of these graduates to become job creators and not job seekers.

The need expressed by Namibia is for education both about and for an enterprise. According to Henry et al. (2005:101), the difference between the two is that the former focuses on mostly awareness creation, and has the specific objective of educating students on the various aspects of setting up and running a business mostly from a theoretical perspective. The latter deals more with the preparation of aspiring entrepreneurs for a career in self-employment with the specific objective of encouraging graduates to set up and run their own businesses. This would benefit the economy with a wider tax basis and relieving pressure from government to provide employment.

To strengthen the economy through new businesses that can contribute to the tax basis, it is necessary to choose the most appropriate learning intervention/model of learning for the specific need required. The specific need is that of entrepreneurial theory, with the emphasis on what must or should be done to start and run a business successfully. The ultimate measure for success of the entrepreneurship education intervention will be the amount of start-ups, and success stories.

There exist various similarities between South Africa and Namibia. Both countries face much the same external environmental issues such as:

- A young elected democratic government.

- The political and legal climate - these external environmental factors are of the utmost importance as it can influence all the other components of the economic system according to Van Aardt (2004:117). This environment has stayed much the same since independence from South Africa in 1990. 
- Economic climate - at the regional level, the South African economy is of major importance and, due to the level of economic integration between South Africa and Namibia, it has a direct impact on the Namibian economy at any given time. Namibia sources some $90 \%$ of its imports from South Africa.

- Social climate - both countries are obliged to increase the welfare of its society with regards to black empowerment, training and development.

- Cultural climate - people in developing nations tend to be heavily dependent on the government to provide for their need, instead of seeking their own solutions (Nieman, 2004:11).

- Demographic factors - a diverse population with an increasing black youth.

Given the above commonalities, an entrepreneurship-education model developed for the South Africa business environment would be more applicable than any other international model. Especially models developed for Europe and American circumstances, where a different business environment is found. One of the prominent differences is that the unemployment rate in Europe and America is low compared to that of South Africa and Namibia. This implies that, in the former countries, entrepreneurship education programs are developed as a career opportunity and in the latter countries as a solution to unemployment. Europe and America are developed countries and Namibia a developing country implying differences in infrastructure, labour cots and productivity to mention a few.

The education programmes used in developed countries like Europe and America have the following objectives (Garavan \& O'Cinneide, 1998:8):

- To acquire knowledge germane to entrepreneurship

- To acquire skills in the use of techniques, in the analysis of business situations, and in the syntheses of action plans

- To identify and stimulate entrepreneurial drive, talent and skills

- To undo the risk-adverse bias of many analytical techniques

- To develop empathy and support for all unique aspects of entrepreneurship

- To devise attitudes towards change

- To encourage new start-ups and other entrepreneurial ventures

The education programme used in South Africa is developed for a developing country focussing on creating capacity and jobs. This led the research to an existing entrepreneurial education model being used for the South African context, as well as a comparison of two models, and an integrated model based on the cited models.

These models are used to show the importance of such models and the need to develop one for Namibia. These models are discussed below.

\section{Entrepreneurial Education Models}

The first model cited was the $\mathrm{E} / \mathrm{P}=[\mathrm{aM}(\mathrm{bE} / \mathrm{S} \times \mathrm{cB} / \mathrm{S})]$ developed to guide syllabi and curriculum development by Van Vuuren and Nieman (1999). This direct linear model suggests that entrepreneurial performance is a function of motivation, entrepreneurial and business skills. These constructs are explained as follows.

$$
\begin{aligned}
& \mathrm{E} / \mathrm{P}=[\mathrm{aM}(\mathrm{bE} / \mathrm{S} \times \mathrm{cB} / \mathrm{S})] \\
& \text { Where } \\
& \mathrm{E} / \mathrm{P}=\text { Entrepreneurial performance } \\
& \mathrm{M}=\text { Motivation } \\
& \mathrm{E} / \mathrm{S}=\text { Entrepreneurial skills } \\
& \mathrm{B} / \mathrm{S}=\text { Business skills } \\
& \mathrm{a} \text { to } \mathrm{c}=\text { constants }
\end{aligned}
$$


These constants are explained by Van Vuuren and Nieman (1999) as:

- Motivation - The development of performance motivation of the entrepreneur is advised for incorporation in all programs. The associated skills include specifically the development of achievement imagery.

- Entrepreneurial skills - Included in this category are various creativity, risk taking and opportunity identification.

- Business skills - This category covers skills such as financial, marketing, operational, human resource, legal, communication, management and business plan compiling skills.

The second model cited for the purpose of entrepreneurial education considers not only the content of entrepreneurial education programmes but also the context in which such programmes are operated by the facilitators and the approaches that they use (Pretorius, 2000a and Pretorius, 2000b). This model identifies five constructs relevant for the education process to increase start-ups and also indicates the relevance of the program context.

The entrepreneurial education model constructs include:

- Entrepreneurial success themes (Gartner et al., 1999:225 and Timmons, 1999:221).

- Business knowledge and skills (Gartner et al., 1999:219 and Harris, 1994:29).

- Business plan utilization (Brush et al., 1995:3 and Timmons, 1999:368).

- Learning approaches (Mayfield \& Weaver, 1997:1 and Ulrich \& Holman, 2000:1).

- The facilitator (McMinn, 2000:24 and Nonis \& Hudson, 1998:4).

This model further has the capacity of a measuring instrument to evaluate existing entrepreneurial programmes.

A comparison of the first two models was done by Pretorius Nieman and Van Vuuren, (2005). The findings of the comparison are explained in Table 1. 
Table 1: Comparison of the education models of van Vuuren and Nieman (1999) and Pretorius (2001)

\begin{tabular}{|c|c|c|}
\hline $\begin{array}{l}\text { Construct } \\
\text { element }\end{array}$ & $\begin{array}{l}\text { Entrepreneurial performance model } \\
\text { according to Van Vuuren and Nieman } \\
\text { (1999) }\end{array}$ & $\begin{array}{l}\text { Entrepreneurial education model } \\
\text { according to Pretorius (2001) }\end{array}$ \\
\hline $\begin{array}{l}\text { Entrepreneurial } \\
\text { performance }\end{array}$ & $\begin{array}{l}\text { Considers the performance of the } \\
\text { individual as entrepreneur (or venture) } \\
\text { and not as manager (where entrepreneur } \\
\text { refer to utilising an opportunity to start a } \\
\text { venture) }\end{array}$ & $\begin{array}{l}\text { The requirements of the context determine } \\
\text { the programme content. One required } \\
\text { outcome is the start-up of a venture }\end{array}$ \\
\hline Motivation (M) & $\begin{array}{l}\text { Motivation as seen as the level of nAch } \\
\text { (need for achievement) of the individual } \\
\text { including: } \\
\text { Desire to be successful and to do well } \\
\text { Urge to improve } \\
\text { Motive to achieve excellence for its own } \\
\text { sake }\end{array}$ & $\begin{array}{l}\text { Absent as a separate construct but } \\
\text { considered partially as an element of E/S } \\
\text { under motivation to excel }\end{array}$ \\
\hline $\begin{array}{l}\text { Entrepreneurial } \\
\text { skills (E/S) }\end{array}$ & $\begin{array}{l}\text { Considers: } \\
\text { Creativity and innovation } \\
\text { Identification of opportunities } \\
\text { Risk taking } \\
\text { Interpretation of role models }\end{array}$ & $\begin{array}{l}\text { Considers: } \\
\text { Commitment } \\
\text { Personal leadership } \\
\text { Opportunity obsession } \\
\text { Tolerance for risk and ambiguity } \\
\text { Creativity } \\
\text { Motivation to excel }\end{array}$ \\
\hline $\begin{array}{l}\text { Business skills } \\
(\mathrm{B} / \mathrm{S})\end{array}$ & $\begin{array}{l}\text { Covers both skills and knowledge } \\
\text { associated with the: } \\
\text { General functions } \\
\text { Life cycle stages of a venture } \\
\text { Business plan }\end{array}$ & $\begin{array}{l}\text { Similar except that the business plan is a } \\
\text { separate construct. }\end{array}$ \\
\hline $\begin{array}{l}\text { Approaches } \\
\text { used to transfer } \\
\text { knowledge and } \\
\text { skills (A) }\end{array}$ & $\begin{array}{l}\text { Absent as it assumes that a motivated } \\
\text { person would find a way to master the } \\
\text { skills once knowledge has been gained }\end{array}$ & $\begin{array}{l}\text { Considers both the: } \\
\text { Involvement of the learner in the learning } \\
\text { process as well as } \\
\text { Variety of learning approaches used }\end{array}$ \\
\hline Facilitator $(F)$ & Absent & $\begin{array}{l}\text { Considers: } \\
\text { Own practical experience } \\
\text { How reinforced thinking is used } \\
\text { Entrepreneurial way of being } \\
\text { Use of apprenticeships } \\
\text { Multidisciplinary approach and thinking }\end{array}$ \\
\hline $\begin{array}{l}\text { Business plan } \\
\text { utilisation }(B / P)\end{array}$ & $\begin{array}{l}\text { Absent as a separate construct but state } \\
\text { under the B/S construct }\end{array}$ & $\begin{array}{l}\text { Coverage of how the business plan is } \\
\text { utilised by: } \\
\text { Preparation } \\
\text { Presentation } \\
\text { Defence } \\
\text { Execution }\end{array}$ \\
\hline $\begin{array}{l}\text { Contextual } \\
\text { description }\end{array}$ & Absent but implied & $\begin{array}{l}\text { Considers: } \\
\text { Previous experience } \\
\text { Minimum education level } \\
\text { Outcomes of the programme } \\
\text { Needs of the target group } \\
\text { Reason for participation }\end{array}$ \\
\hline
\end{tabular}

Based on the above, Pretorius suggests the following integrated model for the purpose of entrepreneurship education. 
Figure 1: Entrepreneurial learning model and constructs (Pretorius, 2001:145)

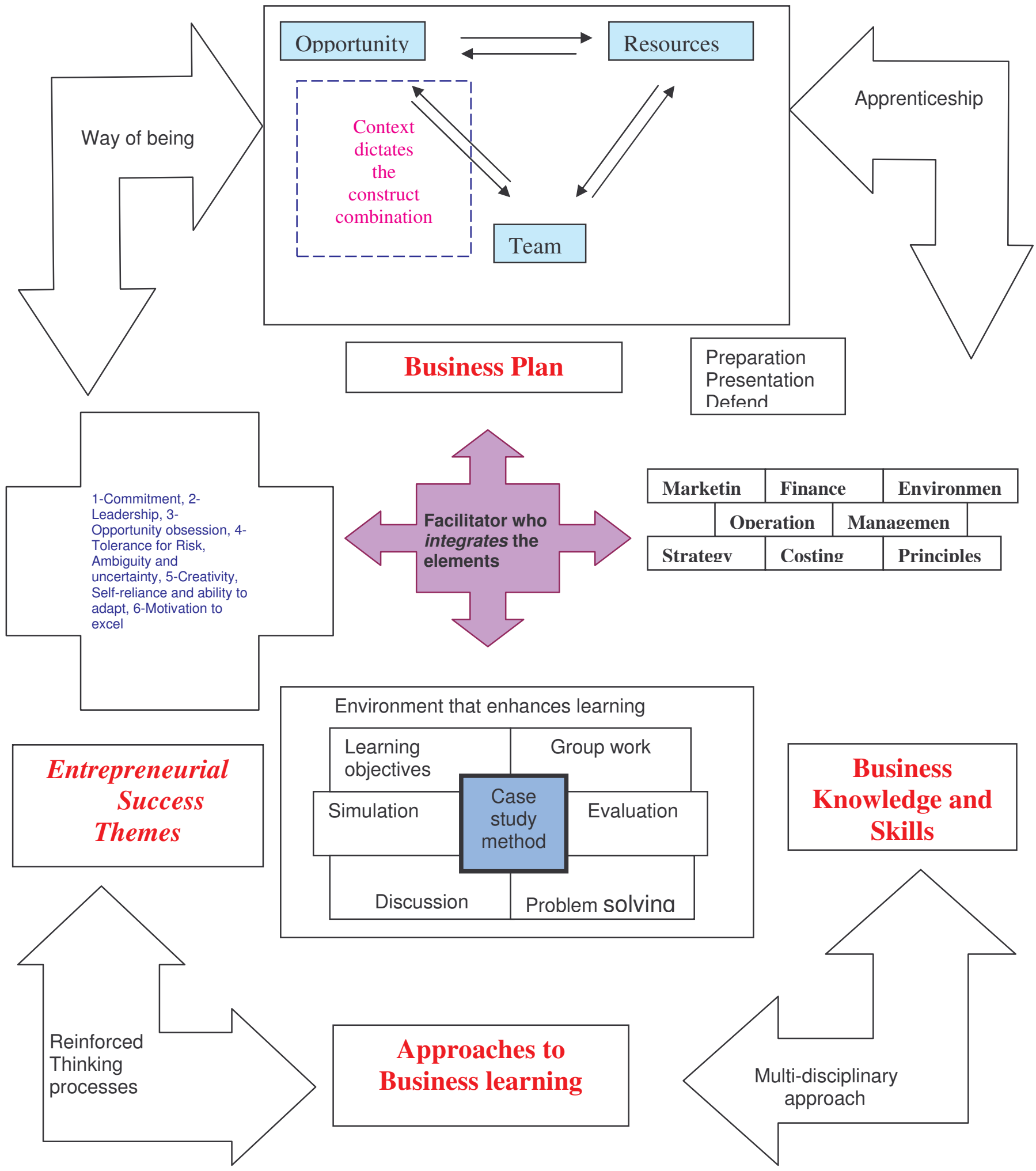


Based on the above, support is found between the needs identified for economic development and the models for entrepreneurial education and therefore the proposition that the components of the South African entrepreneurial education models can be successfully implemented in to the Namibian situation is supported.

\section{RECOMMENDATIONS}

The findings suggest that the model developed by Van Vuuren and Nieman be used as a pilot programme and be phased into the higher education system of Namibia. Once this program is in operation and any limitations are identified, it can be rectified by moving towards the integrated model proposed by Pretorius et al. (2005).

The final education model (Pretorius et al., 2005) is generic in nature and can be applied to the Namibian needs with ease as an appropriate model to base their curriculum on regarding entrepreneurial training. Especially as the discussed models has a focus on entrepreneurship and small business thus covering the total business spectrum.

The relevant stakeholders can engage in a formal discussion by sending a delegation from the Polytechnic from Namibia to visits the Department of Business Management at the University of Pretoria for a workshop to discuss the content of a letter of intent.

This is proposed as a first step to a journey, should both institutions want the opportunity.

Further research should also be conducted in the Namibian context to cater for specific content relevance when a pilot program is developed.

\section{CONCLUSION}

The Polytechnic of Namibia is in need of an appropriate entrepreneurial education model to equip its students with the necessary skills to become job creators and not job seekers. The models investigated are comprehensive in nature and would meet the needs expressed by the Polytechnic to find an appropriate entrepreneurial education model for its curriculum.

\section{REFERENCES}

Brush C, Griffin J \& Smith C. 1995. Perceived value of entrepreneurship course content and pedagogy. In: ICSB Conference, Proceedings:1-6.

Fiet Jo. 2000. The pedagogical side of entrepreneurship theory. Journal of Business Venturing, 16:101117.

Foxcroft M, Wood E, Kew J, Herrington M \& Segal N. 2002. Global Entrepreneurship Monitor: South Africa Executive Report [Online] Available from: www.gemconsortium.org.

Gorman G, Hanlon D \& King W. 1997. Some research perspectives on entrepreneurship education, enterprise education and education for small business management. International Small Business Journal. 15(3):56-77.

Henry C, Hill F \& Leitch C. 2005. Entrepreneurship education and training:can entrepreneurship be taught? Part 1. Education and Training, 47(2): 98-111.

Henry C, Hill F \& Leitch C. 2005. Entrepreneurship education and training:can entrepreneurship be taught? Part II. Education and Training, 47(3):158-169. 
Mayfield WM \& Weaver RY.1997. The Determination of the teaching methodology of entrepreneurship as established by the underlying philosophy of pragmatism. In: ICSB World Conference, Proceedings: San Francisco.

Maasdorp G. 1998. Regional trade and food securityin SADC.Food Policy. 23(6):505-518.

Morris, 1997. Entrepreneurial Intensity. Sustainable advantage for individuals, organizations and societies. Quorum Books.

Namibia 's Ministry of Trade and Industry. 2004. Work document.

Namibian Government. 2004. Namibia National Development Plan.

South African Government. 1996. National small business act, 102. The development and promotion of small business in South Africa - ISBN 0-621-17478-5.

NEPRU BUSINESS CLIMATE SURVEY. 2001. Number 2

NEPRU RESEARCH REPORT. 2002.Number 17

Nieman G, Hough J \& Niewenhuizen. 2004. Entrepreneurship. A South AfricanPerspektive.

Pretorius M. 2000a. A proposed training method for the transfer of skills to enhance micro and small business start-ups in South Africa. International Vocational Education Training Association annual conference, Mauritius.

Pretorius M. 2000b. Evaluation of a proposed training methodology to enhance micro and small business start-ups in South Africa In: Proceedings of the $46^{\text {th }}$ ICSB World Conference. Brisbane. Australia. June.

Pretorius M. 2001. A training model to enhance micro and small business start-ups in South Africa. DTech thesis - Technikon Pretoria.

Pretorius M \& van Vuuren JJ. 2003. The contribution of support and incentive programmes to entrepreneurial orientation and start-up culture in South Africa. South African Journal of Economic and Management Sciences, 6(3):514-528.

Pretorius M \& Nieman GH. 2002. The contribution of formal education to entrepreneurship. A case of

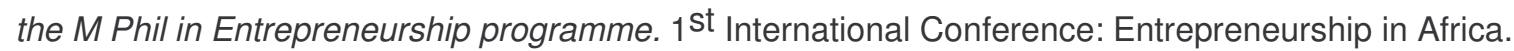
Pretoria, South Africa.

Pretorius M, Nieman GH \& Van Vuuren JJ. 2005. Critical evaluation of two models for entrepreneurship education: An improved model through integration. International Journal of Educational Management, 19(5):413-427.

Proposal For The Development Of Local Capacity In Teaching, Applied Research And Entrepreneurship Polytechnic Of Namibia. 2004.

Stiftung FE. 2000, $12^{\text {th }}$ Round Table on Unemployment, Windhoek

Timmons JA. 1999. New Venture Creation - Entrepreneurship for the $21^{\text {st }}$ century. Irwin McGraw-Hill.

Van Aardt I, Van Aardt C \& Bezuidenhout S. Entrepreneurship and New Venture Management. Oxford University Press. 
Van Vuuren JJ \& Nieman GH. 1999. Entrepreneurial education and training: A model for

syllabi/curriculum development. In: Proceedings of the $45^{\text {th }}$ ICSB World Conference. Naples. Italy. 